\title{
An Analysis of Money Supply in Indonesia: Vector Autoregressive (VAR) Approach
}

\author{
Imamudin YULIADI ${ }^{1}$
}

Received: May 09, 2020 Revised: May 17, 2020 Accepted: June 07, 2020

\begin{abstract}
The role of money in the modern economy highly determines the intensity and the development of the macroeconomy. The money supply is assumed to be as much as money demand, which reflects the economic character of a country and indicates the growth and development of macroeconomy. In Indonesia, the money supply (M1) is related to the economic dynamics in either the monetary market or the goods market. This research aims at analyzing factors that influence the money supply and to what extent the economic factors affect the money supply in Indonesia. The analysis method used in this research was Vector Autoregressive (VAR) with some variables, such as money supply (M1), interest rate, and Gross Domestic Product (GDP) from the 1st quarter of 2001 until the 1st quarter of 2013. The data collection method was in the form of data compilation from credible sources, such as Bank of Indonesia (BI), Central Bureau of Statistics (CBS), and International Financial Statistics (IFS). To obtain adequate analysis results, several tests were taken, such as unit-root test, Granger causality test, and optimal lag. VAR analysis formulates the correlation among independent variables, so it also sees the study of impulse response and matrix decomposition.
\end{abstract}

Keywords : Monetary Policy, Money Supply, Vector Autoregressive, Impulse Response, Indonesia

JEL Classification Code: E51, E52, E58, P24

\section{Introduction}

Economic development in Indonesia experiences some dynamic turbulence due to the dynamic domestic market and the global market. Global economic integration has triggered a strong interaction among world centers of economic growth and new centers for world economic growth in the Asia Pacific and Southeast Asia, including Indonesia (Alalaya, 2016). The economic integration among several countries has become more intensive, especially in the monetary market, which is very sensitive to every change in the global economy. The following curve describes the development of the money supply (M1) in some periods:

${ }^{1}$ First Author and Corresponding Author. Associate Professor, Business and Economic Faculty, Universitas Muhammadiyah Yogyakarta, Indonesia [Postal Address: Jl. Brawijaya, Tamantirto, Kec. Kasihan, Yogyakarta, 55183, Indonesia] Email: imamudin2006@yahoo.co.idn

(c) Copyright: The Author(s)

This is an Open Access article distributed under the terms of the Creative Commons Attribution Non-Commercial License (http://Creativecommons.org/licenses/by-nc/4.0/) which permits unrestricted noncommercial use, distribution, and reproduction in any medium, provided the original work is properly cited.

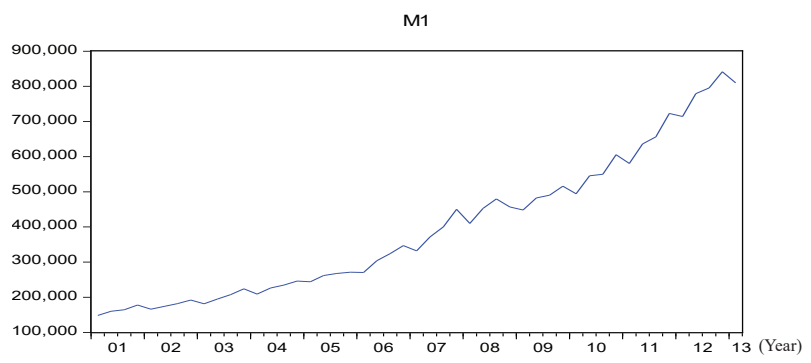

Source: Bank Indonesia

Figure 1: The Development of Money Supply in Indonesia from 2001 - 2013 (trillion rupiahs)

Figure 1 shows that the horizontal line exhibits years, from 2001 to 2013 in quarterly division, while the vertical line displays money supply (M1). The quarterly data show that money supply (M1) significantly and dynamically increases due to economic and non-economic factors. The development of money supply (M1) is related to the development of money demand, which is determined by essential factors of the macroeconomy, such as investment, consumption, export, import, and government's expenses (Alalaya, 2016). The increase of money supply (M1) indicates the increasing 
dynamics of the economy in the real sector and financial sector (He, 2017). The increase in economic growth will support the increase in money supply (M1) and money demand (Tung, 2019). In return, the increase in the money supply will also support the increase in economic growth (Alstadheim, Bache, Holmsen, Maih, \& Røisland, 2010). The fluctuation of the global economy and the escalating price of world oil will influence the moving of money supply through the goods market and monetary market as one of the alternatives of portfolio investment in the monetary market. This research aims at analyzing factors that influence the money supply and to find out the influence of money supply (M1) on other macroeconomic variables (Cevik \& Teksoz, 2013).

The theory that explains money supply is quantity theory, which originates from the classic's point of view. This theory is called Irving Fisher's theory, and it has an equation formula as follows:

$$
\begin{aligned}
& \text { MV = PT } \\
& M=\text { Money supply } \\
& V=\text { Velocity of money } \\
& \mathrm{P}=\text { Price } \\
& \mathrm{T}=\text { Trade }
\end{aligned}
$$

The equation shows that the left side is equal to the right side. The left side is the monetary sector, where the dynamics of the monetary sector is determined by the central bank's policy in changing the money supply and the people's behavior in a transaction using money that influences the velocity of money (He, 2017). Then, on the right side is the real sector, which is defined by economic activities through trade transactions. When the economic condition is under unemployment, the implication is that the increase of money supply through expansive monetary policy will support the rise of real economic sectors. However, in full employment economic conditions, the implication is that the increase in the money supply will support inflation (Alstadheim et al., 2010; Guan \& Lau, 2018; Lubik \& Matthes, 2016; Nawatmi, Nusantara, Santosa, Marlien, \& Udin, 2019; Sethi, Baby, \& Dar, 2019).

Alfred Marshall and Pigou, whose theory is popularly known as Cambridge Theory, have developed theories on money supply beyond classical monetary theories, among others. In their theory, Marshall and Pigou state that the primary aspect of money is as a medium of exchange. This contribution also includes people's behavior in using money (money demand), which is flexible and dynamic. It is contrary to Fisher's view, which states that one's money demand is fixed (Cevik \& Teksoz, 2013).

Another theory that also significantly contributed to the theory of money supply is Keynes' theory, which adds an individual's aspect of motive in holding money. Keynes views money not only as a medium of exchange, but also as a store of value, so people have three motives, namely, transaction motive, precautionary motive, and speculation motive. The level of income determines transaction and precautionary motives, and they correlate positively, while speculation motive is defined by the interest rate. Keynes' thought informs the development of the Cambridge group's thought, which states that people are faced with investment alternatives. Among the few investments are money and wealth, such as securities, land, gold, etc.

In its development, money evolves in accordance with the demand of economic needs. The format and definition of economy is known as money in a narrow sense (M1). M1 is the amount of currency and demands deposits in the society that are distinguished from money in a broad sense (M2). M2 consists of M1 + time deposit and people's savings deposit. Recently, a transaction phenomenon using bank account as the medium emerged, and it is known as electronic money (E-Money). People's need for economic transactions tends to increase, and their desire to use transaction media practically and efficiently triggers many innovations in media, procedures, and payment mechanisms (He, 2017).

The study and research on money supply have been conducted by experts, such as Sargent, Wallace (1973), Thornton (1983), Vitaliano (1984), Kliman (1995), Dumairy (1986), Soelistyo (2003), and Yuliadi (2005). Based on the findings by Domac and Elbirt (1998), money supply (M1) and exchange rate are the main factors that cause inflation. Specifically, an increase of $1 \%$ in money supply (M1) will boost inflation by $0.41 \%$, and $1 \%$ of the exchange rate depression will decrease inflation by $0.25 \%$ (Lubik \& Matthes, 2016).

\section{Research Methods}

\subsection{Unit-roots Test}

To arrive at adequate analysis results, problems related to stationary data should be solved using unit roots tests. Fluctuation analysis of the rupiah exchange rate against the US dollar using the VAR approach requires stationary data of time series. The concept, which was applied to test stationary data of time series, was a unit roots test employing the Augmented Dicky-Fuller test (ADF) method. When time-series data were not stationary, it means that those data had a unit-roots problem, which resulted in spurious data and invalid analysis results. To detect the unit-roots problem, the value of t-statistics as the result of regression could be compared with the value of Augmented Dickey-Fuller (ADF). The equity model was formulated in the following (Gujarati \& Porter, 2002).

$$
\Delta \mathrm{M}_{\mathrm{t}}=\mathrm{a}_{1}+\mathrm{a}_{2} \mathrm{~T}+\Delta \mathrm{M}_{\mathrm{t}-1}+\mathrm{a}_{\mathrm{i}} \Delta \mathrm{M}_{\mathrm{t}-1}+e_{\mathrm{t}}
$$

Where $\Delta \mathrm{M}_{\mathrm{t}-1}=\left(\Delta \mathrm{M}_{\mathrm{t}-1}-\Delta \mathrm{M}_{\mathrm{t}-2}\right)$, and so on, $\mathrm{m}=$ length of time-lag based on $\mathrm{i}=1.2 . . \mathrm{m}$. Null hypothesis stays 
$\delta=0$ or $\rho=1$. The t-statistics values of ADF are the same as the t-statistics value of DF. Unit roots tests could be done utilizing the Phillips-Perron test model. Data are stationary when the value of the statistics of ADF is more than the table value with a critical value of $5 \%$ or $10 \%$.

\subsection{Granger Causality Test}

The fluctuation analysis of the rupiah exchange rate against the US dollar considers the influence among macroeconomic variables, such as foreign exchange reserves, exchange rate, interest rate, inflation, and GDP. Granger causality test was used to find out if there was any causality among the variables. There are some possibilities of Granger causality tests such as one-way causality, two ways causality, and no causality among the variables.

\subsection{Analysis of Vector Autoregressive (VAR)}

Vector Autoregressive (VAR) analysis is an analysis model of a dynamic economy that includes the change of time-lag in the variables. The dynamic behaviors among the observed variables of Vector Autoregressive analysis would be explained further through property functions, namely, Impulse Response function and Variance Decomposition function.

Vector Autoregression analysis model could also be implemented to expect and to project the amount of a variable. Thus, in seeing the market phenomena in which the exchange rate fluctuates significantly, the value of rupiah in specific periods can be identified. The model of the Indonesian macroeconomy represents the economic model of a small country, so Vector Autoregressive Analysis considers that the model, which is estimated in a particular condition, can be used to predict different time conditions and policies. Vector Autoregressive Analysis can also include an element of shock in the analyzed model as well as see the long-term response based on the historical data. The research about exchange rate fluctuation is very sensitive to an economic shock, which comes from either the domestic or foreign market. The sensitivity of the monetary market is highly influenced by economic factors and institutions, including the government's policy and the stability of national political security. Vector Autoregressive is one of the analysis tools that not only functions to see the causal correlation among variables, but also to see to the extent of the influence of economic shock towards exchange rate stability. The dynamic values among the observed variables examining the impact of shock at Vector Autoregressive Analysis would be explained further through Impulse Response Function and Variance Decomposition (Lubik \& Matthes, 2016).

Subjects were chosen based on answers that showed the difficulty in establishing formal proof verification related to conceptual understanding, referential reasoning, and organization of proof-writing. Task-based interviews were needed to track the thinking process and possible causes of errors.

\section{Results and Discussion}

This research analyzed the money supply in Indonesia from the 1st quarter of 2001 to the 1 st quarter of 2013 by including research variables, which consisted of:

DPDB $=$ National income

DM1 = Money supply (M1)

$\mathrm{DR}=$ Deposit interest rate

The first step in researching the exchange fluctuation was by observing the character of the data, whether they were stationary or not. This research processed data using the Eviews program, and to find out the stationary data, the unit-roots test was done through Augmented DickeyFuller test on some variables consisting of national income (DPDB), money supply (DM1), and interest rate (DR). The result of the analysis showed that DPDB, interest rate, and money supply (DM1) were not stationary at their level. To get stationary data, first difference and second difference tests were conducted. The result indicated that interest rate, DPDB, and DM1 were stationary at the second difference.

The next step was determining optimal lag, which was defined by final prediction error (FPE), Akaike information criterion (AIC), Schwarz criterion (SC), and Hannan-Quinn (HQ). The data processing employing the Eviews program shows the following result:

Table 1 shows that at lag 3 , the value of final prediction error (FPE), the value of Akaike information criterion (AIC), Schwarz criterion (SC), and Hannan-Quinn (HQ) show an asterisk (*). It means that optimal lag occurred at lag 3. Also, it showed that the influence of variable change included the change until lag 3.

\subsection{Granger Causality Test}

VAR analysis explains the influence among independent variables in the research, including the dynamic impact in some previous periods. Through the Granger causality test, the causality of the research variables can be known. Granger causality test also functions to find out the correlation of one variable with other variables. The result of the Granger causality test is shown in the table below:

The result of the Granger causality test in Table 2 showed that DPDB influenced money supply, and in return, money supply (DM1) affected DPDB. This economic phenomenon is in line with the view of the monetarists that states that money supply (DM1) can support economic growth when the condition is underemployment, and it will cause inflation when the condition is full employment (Maier, 2010). 
Table 1: VAR Lag Order Selection Criteria

\begin{tabular}{|c|c|c|c|c|c|c|}
\hline Lag & LogL & LR & FPE & AIC & SC & HQ \\
\hline 0 & -941.8601 & NA & $2.45 \mathrm{e}+15$ & 43.94698 & 44.06986 & 43.99229 \\
\hline 1 & -872.7603 & 125.3439 & $1.50 \mathrm{e}+14$ & 41.15164 & 41.64314 & 41.33289 \\
\hline 2 & -813.8832 & 98.58486 & $1.48 \mathrm{e}+13$ & 38.83178 & 39.69190 & 39.14896 \\
\hline 3 & -795.4179 & $28.34213^{*}$ & $9.71 \mathrm{e}^{*}+12^{*}$ & $38.39153^{*}$ & $39.62027^{*}$ & $38.84465^{*}$ \\
\hline 4 & -789.8551 & 7.761996 & $1.18 \mathrm{e}+13$ & 38.55140 & 40.14877 & 39.14046 \\
\hline * indicates lag order selected by the criterion & & & \\
\hline \\
LR: sequential modified LR test statistic (each test at $5 \%$ level) \\
\hline
\end{tabular}

Table 2: Pairwise Granger Causality Tests

\begin{tabular}{|c|c|c|c|}
\hline Null Hypothesis: & Obs & F-Statistic & Prob. \\
\hline DPDB does not Granger Cause DM1 & 45 & 18.5021 & 2.E-06 \\
\hline \multicolumn{2}{|l|}{ DM1 does not Granger Cause DPDB } & 26.1871 & 5.E-08 \\
\hline DR does not Granger Cause DM1 & 45 & 18.5849 & 2.E-06 \\
\hline \multicolumn{2}{|l|}{ DM1 does not Granger Cause DR } & 10.7193 & 0.0002 \\
\hline DR does not Granger Cause DPDB & 45 & 60.7681 & 8.E-13 \\
\hline \multicolumn{2}{|l|}{ DPDB does not Granger Cause DR } & 29.2708 & 1.E-08 \\
\hline
\end{tabular}

On the other hand, economic growth will also support the increase of money supply, which is in line with the theory of the monetary economy that states that the rise of economic growth triggers the increase in liquidity needs to support the economic transaction, so that money supply (DM1) will also increase. Granger Causality test also stated that the interest rate (DR) influenced money supply (DM1), and in return, money supply (DM1) affected the interest rate (DR). This monetary phenomenon could be explained through IS-LM analysis in which the increase of money supply (DM1) was indicated by the movement of the LM curve to the bottom right so that it would cause a decrease in interest rate (DR). On the contrary, the change of interest rate would influence DM1 through expansive or contractive monetary policy instruments that could influence DM1 in society. Interest rate (DR) affected DPDB, and in return, DPDB also impacted the interest rate (DR) (Cevik \& Teksoz, 2013).

\subsection{Vector Autoregressive (VAR) Analysis}

VAR analysis was carried out to get information about the correlation among the research variables at a lot of time lags before. The following chart presents the result of VAR analysis employing Eviews program:

The results in Table 3 explained that the estimated value of the correlation among the variables consisted of national income (DPDB), money supply (DM1), and interest rate (DR). The value above exhibited the coefficient value, while the value in brackets presented the standard value of error, and the value in [ ] showed the t-statistic value. Based on VAR analysis, VAR model was formulated with the following result:

VAR Model:

$\mathrm{DM} 1=\mathrm{C}(1,1) * \mathrm{DM} 1(-1)+\mathrm{C}(1,2) * \mathrm{DM} 1(-2)+$ $\mathrm{C}(1,3) * \mathrm{DM} 1(-3)+\mathrm{C}(1,4) * \mathrm{DPDB}(-1)+\mathrm{C}(1,5) * \mathrm{DPDB}(-2)$ 
Table 3: Vector Autoregression Estimates

\begin{tabular}{|c|c|c|c|}
\hline & DM1 & DPDB & DR \\
\hline \multirow{3}{*}{ DM1(-1) } & 0.339648 & -0.009744 & $-6.63 E-07$ \\
\hline & $(0.17161)$ & $(0.03243)$ & (6.7E-07) \\
\hline & [1.97913] & {$[-0.30044]$} & {$[-0.98764]$} \\
\hline \multirow[t]{3}{*}{ DM1(-2) } & -0.328507 & 0.036910 & $-3.77 \mathrm{E}-07$ \\
\hline & $(0.17155)$ & $(0.03242)$ & (6.7E-07) \\
\hline & [-1.91488] & [1.13853] & {$[-0.56225]$} \\
\hline \multirow[t]{3}{*}{ DM1(-3) } & 0.162954 & -0.006593 & $-1.53 E-06$ \\
\hline & $(0.17463)$ & $(0.03300)$ & (6.8E-07) \\
\hline & [0.93313] & {$[-0.19980]$} & {$[-2.24469]$} \\
\hline \multirow[t]{3}{*}{ DPDB(-1) } & 1.346585 & 0.712240 & $1.04 \mathrm{E}-05$ \\
\hline & $(0.75654)$ & $(0.14297)$ & (3.0E-06) \\
\hline & [1.77993] & [ 4.98189] & [3.52108] \\
\hline \multirow[t]{3}{*}{ DPDB(-2) } & -0.844962 & -0.987312 & $2.81 \mathrm{E}-07$ \\
\hline & $(0.35233)$ & $(0.06658)$ & (1.4E-06) \\
\hline & {$[-2.39823]$} & {$[-14.8288]$} & [0.20365] \\
\hline \multirow[t]{3}{*}{ DPDB(-3) } & 0.914089 & 0.641204 & 8.64E-06 \\
\hline & $(0.78944)$ & $(0.14918)$ & (3.1E-06) \\
\hline & [1.15789] & [ 4.29807] & [2.79828] \\
\hline \multirow[t]{3}{*}{$\mathrm{DR}(-1)$} & 38735.31 & -3817.332 & 0.876399 \\
\hline & $(38656.1)$ & $(7305.00)$ & $(0.15120)$ \\
\hline & [ 1.00205$]$ & {$[-0.52256]$} & [ 5.79633] \\
\hline \multirow[t]{3}{*}{$\mathrm{DR}(-2)$} & -36246.91 & 13742.00 & -0.391885 \\
\hline & $(50822.3)$ & (9604.09) & $(0.19879)$ \\
\hline & {$[-0.71321]$} & [1.43085] & {$[-1.97139]$} \\
\hline \multirow[t]{3}{*}{$\mathrm{DR}(-3)$} & 46716.13 & -461.8165 & 0.335132 \\
\hline & $(39475.0)$ & $(7459.75)$ & $(0.15440)$ \\
\hline & [1.18343] & {$[-0.06191]$} & [2.17051] \\
\hline \multirow[t]{3}{*}{ C } & -7062.231 & 6026.527 & -0.126190 \\
\hline & $(12464.6)$ & $(2355.48)$ & $(0.04875)$ \\
\hline & {$[-0.56658]$} & [ 2.55851] & {$[-2.58831]$} \\
\hline R-squared & 0.773591 & 0.966673 & 0.934007 \\
\hline $\begin{array}{l}\text { Adj. } \\
\text { R-squared }\end{array}$ & 0.713659 & 0.957851 & 0.916538 \\
\hline Sum sq. resids & $7.27 E+09$ & $2.59 \mathrm{E}+08$ & 0.111156 \\
\hline S.E. equation & 14618.26 & 2762.469 & 0.057178 \\
\hline F-statistic & 12.90785 & 109.5773 & 53.46744 \\
\hline Log likelihood & -478.7222 & -405.4118 & 69.14900 \\
\hline Akaike AIC & 22.21465 & 18.88235 & -2.688591 \\
\hline Schwarz SC & 22.62014 & 19.28785 & -2.283093 \\
\hline $\begin{array}{l}\text { Mean } \\
\text { dependent }\end{array}$ & 29722.80 & 13835.59 & 0.280000 \\
\hline $\begin{array}{l}\text { S.D. } \\
\text { dependent }\end{array}$ & 27318.33 & 13455.65 & 0.197917 \\
\hline \multicolumn{2}{|c|}{$\begin{array}{l}\text { Determinant resid covariance } \\
\text { (dof adj.) }\end{array}$} & 4.84E+12 & \\
\hline \multicolumn{2}{|c|}{ Determinant resid covariance } & $2.23 \mathrm{E}+12$ & \\
\hline \multicolumn{2}{|l|}{ Log-likelihood } & -812.8368 & \\
\hline \multicolumn{2}{|c|}{ Akaike information criterion } & 38.31076 & \\
\hline \multicolumn{2}{|c|}{ Schwarz criterion } & 39.52726 & \\
\hline
\end{tabular}

$+\mathrm{C}(1,6) * \mathrm{DPDB}(-3)+\mathrm{C}(1,7) * \mathrm{DR}(-1)+\mathrm{C}(1,8) * \mathrm{DR}(-2)+$ $\mathrm{C}(1,9) * \mathrm{DR}(-3)+\mathrm{C}(1,10)$

$\mathrm{DPDB}=\mathrm{C}(2,1) * \mathrm{DM} 1(-1)+\mathrm{C}(2,2) * \mathrm{DM} 1(-2)+$ $\mathrm{C}(2,3) * \mathrm{DM} 1(-3)+\mathrm{C}(2,4) * \mathrm{DPDB}(-1)+\mathrm{C}(2,5) * \mathrm{DPDB}(-2)$ $+\mathrm{C}(2,6) * \mathrm{DPDB}(-3)+\mathrm{C}(2,7) * \mathrm{DR}(-1)+\mathrm{C}(2,8) * \mathrm{DR}(-2)+$ $\mathrm{C}(2,9) * \mathrm{DR}(-3)+\mathrm{C}(2,10)$

$\mathrm{DR}=\mathrm{C}(3,1) * \mathrm{DM} 1(-1)+\mathrm{C}(3,2) * \mathrm{DM} 1(-2)+$ $\mathrm{C}(3,3) * \mathrm{DM} 1(-3)+\mathrm{C}(3,4) * \mathrm{DPDB}(-1)+\mathrm{C}(3,5) * \mathrm{DPDB}(-2)$ $+\mathrm{C}(3,6) * \mathrm{DPDB}(-3)+\mathrm{C}(3,7) * \mathrm{DR}(-1)+\mathrm{C}(3,8) * \mathrm{DR}(-2)+$ $\mathrm{C}(3,9) * \mathrm{DR}(-3)+\mathrm{C}(3,10)$

VAR Model - Substituted Coefficients:

$\mathrm{DM} 1=$

$0.339648023655 * \mathrm{DM} 1(-1)-0.328506966907 * \mathrm{DM} 1(-2)$ $+0.162953845078 * \mathrm{DM} 1(-3)+1.34658471517 * \mathrm{DPDB}(-1)-$ $0.844961927549 * \mathrm{DPDB}(-2)+0.914088516753 * \mathrm{DPDB}(-$ $3)+38735.3116708 * \mathrm{DR}(-1)-36246.9129662 * \mathrm{DR}(-2)$ $+46716.1250441 * \mathrm{DR}(-3)-7062.23143346$

$\mathrm{DPDB}=-0.00974352997866 * \mathrm{DM} 1(-1)+0.0369101803249 *$ DM1(-2) - 0.00659346613589*DM1(-3) +

$0.712239674928 * \mathrm{DPDB}(-1)-0.987312018336 * \mathrm{DPDB}(-$ $2)+0.641203668993 * \operatorname{DPDB}(-3)-$

$3817.33199951 * \mathrm{DR}(-1)+13741.9958003 * \mathrm{DR}(-$

2) $-461.816509449 * \mathrm{DR}(-3)+6026.52693176$

$\mathrm{DR}=-6.62954868253 \mathrm{e}-07 * \mathrm{DM} 1(-1)-$

$3.77280269785 \mathrm{e}-07 * \mathrm{DM} 1(-2)-$

$1.53324301121 \mathrm{e}-06 * \mathrm{DM} 1(-3)+$

$+2.80648928531 \mathrm{e}-07 * \mathrm{DPDB}(-2)+$

$1.04192429191 \mathrm{e}-05 * \mathrm{DPDB}(-1)$

8.64059184516e-06*DPDB $(-3)+$

$0.876398968573 * \mathrm{DR}(-1)-0.391884678211 * \mathrm{DR}(-2)+$ $0.33513151383 * \mathrm{DR}(-3)-0.12619001258$

The first VAR model showed that money supply (DM1) was influenced by the money supply in the previous periods from the first period in which DM1(-1) until the third period in which DM1(03), with different changes. This condition could be seen from the coefficient value of regression and t-statistic value, which revealed a different number, in which the value in the first quarter was 0.339648 , with the $\mathrm{t}$-statistic value of 1.97913 bigger than the t-table. Then, the coefficient regression was -0.328506 in the second quarter before. After that, the coefficient value was 0.1629538 in the previous third quarter, with a t-statistic that was smaller than the t-table. This monetary phenomenon generally indicated the trend of increasing money supply, which is in accordance with the monetary policy pattern made by the government, which states that the trend of increasing the money supply will continue to happen along with the increase of money demand for society's transaction. 
The regression coefficient of national income variable (DPDB) displayed significant value of influence brought by national income variable (DPDB) in the previous quarter period, which generally indicated an increasing trend from time to time. The previous economic performance significantly influenced the next economic performance. Meanwhile, the regression coefficient value of interest rate (DR) was influenced by money supply (DM1) in the previous quarter with regression coefficient value, which was relatively small (-0.0000015) (Cevik \& Teksoz, 2013; Rahman \& Mustafa, 2017).

\subsection{Impulse Response Function}

To complete VAR analysis, impulse response function analysis was conducted to find out the influence of shock to the economy in overcoming the problem of interpreting the result of VAR analysis. The function of impulse response depicts the velocity of shock in one variable to the other variables until its influence disappears, and it returns to a balanced position. On the other side, the impulse response function can also trace the response of the dependent variable if there is a shock in $u_{1}$ and $u_{2}$
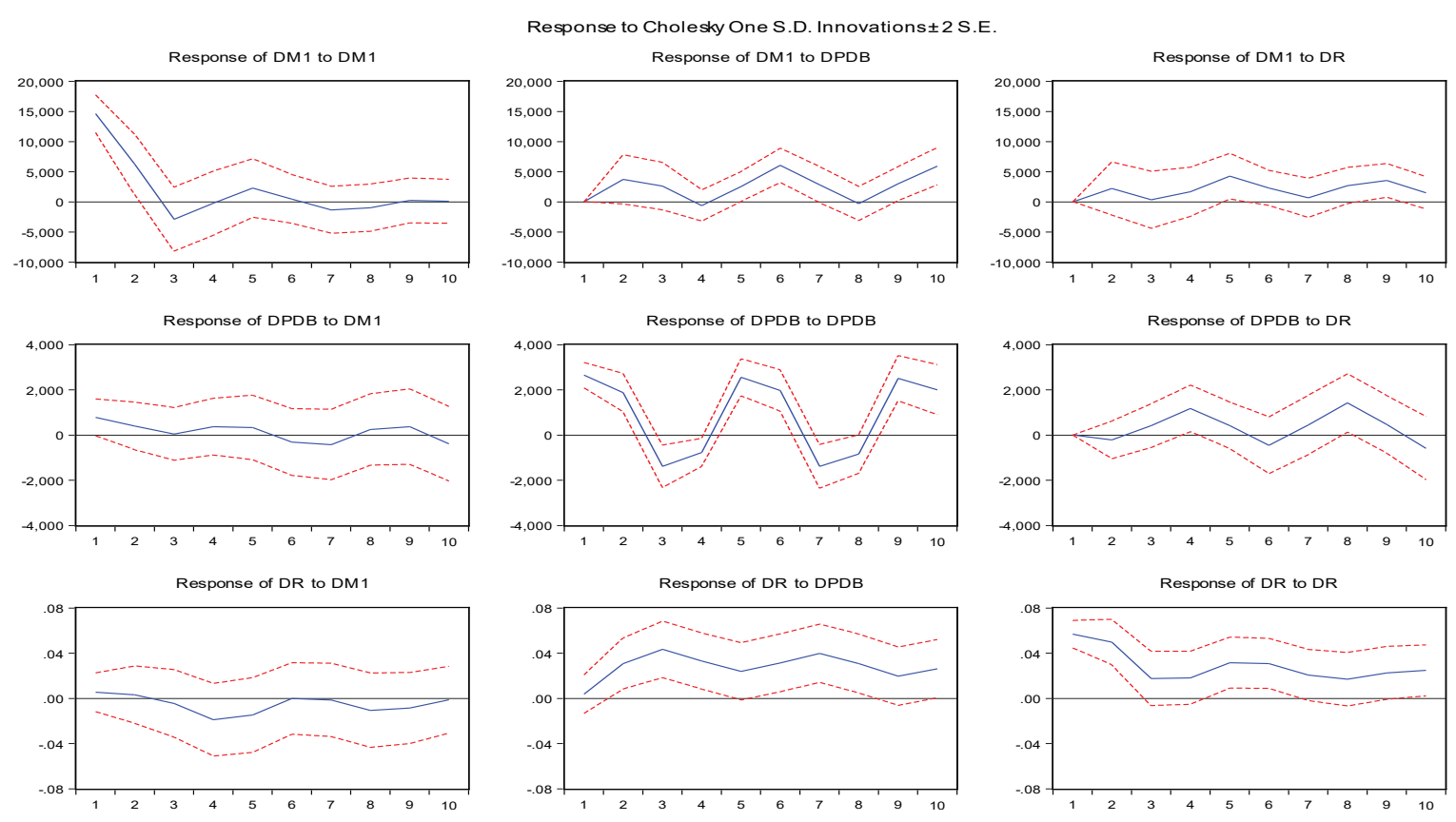

Figure 2: The Impulse Response Function Analysis

The analysis of the impulse response function in Figure 2 showed that the center-left quadrant described the change of DPDB as a response to the change in the money supply (DM1) (Maier, 2010). The first to the third quarter indicated a decrease in DPDB change in response to the change of money supply (DM1), with a relatively small response towards the balance point. Then, a slight increase occurred in the fourth and fifth quarters and dropped back to the balance point in the sixth quarter. The center quadrant described the change of money supply (DM1) as a response to the change of DPDB (Rahman \& Mustafa, 2017).

There was a pattern tendency that money supply (DM1) increased again after reaching the balance point as it could be seen that, from the first quarter to the second quarter, the money supply tended to increase after the decrease in the third quarter and reached the balance point in the fourth quarter. After that, the money supply (DM1) responded to the DPDB change, which was increasing, and so on. More or less, the same pattern happened in the right quadrant which described the change of money supply (DM1) to respond the change of interest rate (DR), in which the first quarter to the second quarter revealed a tendency of the increase of money supply (DM1), then decreased and reached the balance point in the third quarter. After that, it increased again and so on. What marks a difference with the previous pattern was that the change of money supply (DM1), which responded to the change of interest rate, had an intensity which was not too big (He, 2017; Maier, 2010).

\subsection{Analysis of Variance Decomposition}

Analysis of variance decomposition provides information about the movement proportion of shock influence in one variable to the other variables in one current period and the next period. 
Table 4: Variance Decomposition of DM1

\begin{tabular}{|c|c|c|c|c|}
\hline Period & S.E. & DM1 & DPDB & DR \\
\hline 1 & 14618.26 & 100.0000 & 0.000000 & 0.000000 \\
\hline 2 & 16466.65 & 93.13802 & 5.076813 & 1.785167 \\
\hline 3 & 16922.28 & 91.09847 & 7.174384 & 1.727146 \\
\hline 4 & 17016.83 & 90.10884 & 7.229424 & 2.661732 \\
\hline 5 & 17866.82 & 83.37344 & 8.567275 & 8.059281 \\
\hline 6 & 19011.82 & 73.69314 & 17.73732 & 8.569545 \\
\hline 7 & 19277.14 & 72.16561 & 19.38244 & 8.451951 \\
\hline 8 & 19491.30 & 70.84338 & 18.98189 & 10.17473 \\
\hline 9 & 20039.43 & 67.03332 & 20.22025 & 12.74643 \\
\hline 10 & 20945.90 & 61.35817 & 26.47367 & 12.16816 \\
\hline \multicolumn{5}{|c|}{ Variance Decomposition of DPDB: } \\
\hline Period & S.E. & DM1 & DPDB & DR \\
\hline 1 & 2762.469 & 8.088501 & 91.91150 & 0.000000 \\
\hline 2 & 3367.519 & 6.828991 & 92.75646 & 0.414548 \\
\hline 3 & 3664.771 & 5.782999 & 92.58685 & 1.630154 \\
\hline 4 & 3942.426 & 5.866710 & 83.79824 & 10.33505 \\
\hline 5 & 4727.737 & 4.571524 & 87.44553 & 7.982943 \\
\hline 6 & 5150.456 & 4.214131 & 88.27060 & 7.515270 \\
\hline 7 & 5367.967 & 4.505368 & 87.88921 & 7.605425 \\
\hline 8 & 5621.128 & 4.294943 & 82.38610 & 13.31895 \\
\hline 9 & 6184.823 & 3.908474 & 84.52085 & 11.57068 \\
\hline 10 & 6538.842 & 3.850018 & 84.99226 & 11.15772 \\
\hline \multicolumn{5}{|c|}{ Variance Decomposition of DR: } \\
\hline Period & S.E. & DM1 & DPDB & DR \\
\hline 1 & 0.057178 & 0.899124 & 0.422405 & 98.67847 \\
\hline 2 & 0.081911 & 0.595173 & 14.39153 & 85.01330 \\
\hline 3 & 0.094461 & 0.682197 & 31.90240 & 67.41540 \\
\hline 4 & 0.103457 & 3.913620 & 36.78639 & 59.29999 \\
\hline 5 & 0.111754 & 5.093877 & 36.06818 & 58.83794 \\
\hline 6 & 0.120135 & 4.408017 & 38.06935 & 57.52263 \\
\hline 7 & 0.128255 & 3.879205 & 43.06447 & 53.05633 \\
\hline 8 & 0.133395 & 4.212594 & 45.13206 & 50.65534 \\
\hline 9 & 0.136961 & 4.386428 & 44.85752 & 50.75605 \\
\hline 10 & 0.141636 & 4.109651 & 45.37668 & 50.51367 \\
\hline
\end{tabular}


The first part in Table 4 explains that the first period of money supply (DM1) is $100 \%$ influenced by the money supply (DM1) itself, while the other variables such as national income (DPDB) and interest rate (DR) contribute $0 \%$. In the second period, the contribution of money supply (DM1) was as much as $93.13 \%$, while national income (DPDB) was $5.07 \%$, and the interest rate (DR) was $1.78 \%$. In the third period, the contribution of money supply (DM1) was $91.09 \%$, national income (DPDB) was $7.17 \%$, and interest rate (DR) was $1.727 \%$. In the fourth period, the money supply was $90.1 \%$, national income (DPDB) was $7.22 \%$, and interest rate (DR) was $2.66 \%$. In the fifth period, the contribution of the money supply (DM1) was $83.37 \%$, national income (DPDB) was $8.56 \%$, and the interest rate was $8.06 \%$. From the first table, it can be seen that the contribution of national income (DPDB) to the money supply (DM1) was gradual and stable. Still, the contribution of interest rate (DR) was rather drastic especially in the fourth period to the fifth period, where the contribution of interest rate (DR) in the fourth period was $2.66 \%$, but increased sharply to $8.06 \%$ in the fifth period (Medhioub \& Jedidia, 2017).

This phenomenon showed that there was a process of the transmission mechanism in the monetary market so that the change of interest rate (DR) could influence the money supply (DM1). The second table shows the reality of the contribution of national income (DPDB) in the first period, in which the contribution of money supply (DM1) was $8.08 \%$, national income (DPDB) was $91.91 \%$, and interest rate (DR) was $0 \%$. This phenomenon indicated that the contribution of money supply (DM1) to national income (DPDB) was relatively big and significant, as it could be seen that in the same period, the contribution of money supply (DM1) was fairly big to the national income (DPDB). This phenomenon exhibited that the monetary policy is effective enough to influence the increase of economic growth under employment conditions, as seen by the monetarists. The second period displayed a reality of the contribution of national income (DPDB), in which the contribution of money supply (DM1) was $6.82 \%$, national income (DPDB) was $92.75 \%$, and interest rate (DR) was $0.4 \%$. The third period presented the fact about the contribution of national income (DPDB), in which the money supply (DM1) was 5.78\%, national income (DPDB) was $92.58 \%$, and interest rate (DR) was $1.63 \%$. The fourth period demonstrated the contribution of national income (DPDB), in which the contribution of money supply (DM1) was $5.86 \%$, national income (DPDB) was $83.79 \%$, and interest rate (DR) was $10.33 \%$ (Medhioub \& Jedidia, 2017).

The second part in Table 4 describes an interesting phenomenon in which the contribution of money supply (DM1) is relatively stable to the national income (DPDB), but is different with the contribution of the interest rate (DR), in which there is a fairly big spike from the third period to the fourth period or from $1.63 \%$ to $10.33 \%$. This phenomenon showed that monetary instrument - interest rate (DR) was relatively very sensitive to influence economic growth (DPDB) after entering the third and fourth periods.

The third part in Table 4 shows the fact about the contribution to interest rate (DR) in the first period, in which money supply (DM1) is $0.89 \%$, national income (DPDB) is $0.42 \%$, and interest rate (DR) is $98.67 \%$. This phenomenon indicated that the contribution of money supply (DM1), national income (DPDB), and interest rate (DR) was relatively significant, as it could be seen that in the first period the contribution of money supply (DM1) was significant enough as it was $0.89 \%$. This phenomenon exhibited that the real market had a sensitive influence on the monetary sector. The second period presented the reality of the contribution of interest rate (DR), in which the contribution of money supply (DM1) was $0.59 \%$, national income (DPDB) was $14.39 \%$, and interest rate (DR) was $85.03 \%$. The third period explained the fact about the contribution to interest rate (DR), in which the contribution of money supply (DM1) was $0.68 \%$, national income (DPDB) was $31.9 \%$, and the interest rate was $67.41 \%$. The fourth period displayed the contribution to interest rate (DR), in which the contribution of money supply (DM1) was 3.91\%, national income (DPDB) was $36.78 \%$, and interest rate (DR) was $59.81 \%$. An interesting phenomenon could be seen in which the contribution of money supply (DM1) was relatively significant and stable to the interest rate (DR). Still, it was different from the contribution of national income (DPDB) to interest rate (DR), in which there was a fairly big spike from the second period to the third period or from $14.39 \%$ to $31.9 \%$. This phenomenon revealed that the real sector phenomenon had a relatively significant influence on the change of interest rate (DR) (He, 2017).

\section{Conclusion}

The research about money supply in Indonesia, produced the following information:

The money supply had implications for the goods market and monetary market that was reciprocal, which means that the dynamics of the monetary market and goods market influenced the money supply and vice versa, as shown in the Granger causality test. Meanwhile, the impact of the money supply on the goods market in this research was demonstrated by its influence on national income (DPDB) (Baffes, O’Connell, \& Elbadawi, 1999).

In the first period, the change of money supply (DM1) was influenced $100 \%$ by the money supply (DM1) itself, while other variables, such as national income (DPDB) and interest rate (DR) contributed $0 \%$. Meanwhile, in the second period, the contribution of money supply (DM1) was $93.13 \%$, national income (DPDB) was 5.97\%, and interest rate (DR) was $1.78 \%$. The variance decomposition 
analysis revealed that, in the first period, the contribution of money supply (DM1) was influenced $100 \%$ by money supply itself, while national income (DPDB) and interest rate (DR) contributed $0 \%$. In the second period, the contribution of money supply (DM1) was $93.13 \%$, national income (DPDB) was $5.07 \%$, and interest rate (DR) was $1.78 \%$. This phenomenon showed that there was a process of the transmission mechanism in the monetary market, so that the change of interest rate (DR) could influence the money supply (DM1) (Alalaya, 2016).

The contribution to national income (DPDB) in the first period accounted to $8.08 \%$ of money supply (DM1), $91.91 \%$ of national income (DPDB), and $0 \%$ of interest rate (DR). This phenomenon showed that the contribution of money supply (DM1) to national income (DPDB) was relatively high and significant, as it could be seen in the same period that the contribution of money supply (DM1) was relatively big to national income (DPDB). This phenomenon exhibited that monetary policy was effective enough to influence the increase of economic growth when the condition was underemployment, as seen by the monetarists. The second period explained the fact about the contribution of national income (DPDB), in which the contribution of national income (DPDB) was 6.82\%, national income (DPDB) was $92.75 \%$, and interest rate (DR) was $0.4 \%$.

The suggestions for this research are formulated as follows:

The transmission of mechanism in money supply to the real sector - the improvement of economic growth in Indonesia - needs the role and performance of the monetary sector through enhancing the efficiency of monetary and banking institutions and eliminating economic distortion either in the real sector or monetary sector.

It is necessary to formulate appropriate monetary policy to face the global economic fluctuation employing monetary instruments that can anticipate the change in the global economy.

The improvement of macroeconomy fundamentals is made through policies of increasing exports, investment climates, the creation of good and clean governance, and increasing the efficiency of the monetary sector as an intermediary institution.

\section{References}

Alalaya, M. (2016). Monetary Transmission Mechanisms Through Var Model: Evidence From Jordan (1988-2013). International Journal of Economics, Commerce and Management, 4(7), 83107.
Alstadheim, R., Bache, I. W., Holmsen, A., Maih, J., \& Røisland, Ø. (2010). Monetary policy analysis in practice: Staff Memo.

Baffes, J., O’Connell, S. A., \& Elbadawi, I. A. (1999). Singleequation estimation of the equilibrium real exchange rate. Exchange Rate Misalignment: Concepts And Measurement For Developing Countries (pp. 405-464): The World Bank.

Cevik, S., \& Teksoz, K. (2013). Lost in Transmission? The Effectiveness of Monetary Policy Transmission Channels in the GCC Countries. Middle East Development Journal, 5(3), DOI: 10.1142/S1793812013500181

Guan, L.-F., \& Lau, W.-Y. (2018). Triffin Dilemma and International Monetary System : Evidence from Pooled Mean Group Estimation. Journal of Asian Finance, Economics and Business, 5(2), 5-14. http://doi.org/10.13106/jafeb.2018.vol5. no2.5

Gujarati, D. N., \& Porter, D. (2002). Basic Econometrics. New York: McGraw Hill.

He, L. T. (2017). Emphasis and effectiveness of monetary policy of the Fed: a historical comparative analysis (1871-2013). International Journal of Monetary Economics and Finance, 10(1), 47-67.

Lubik, T. A., \& Matthes, C. (2016). Indeterminacy and learning: An analysis of monetary policy in the Great Inflation. Journal of Monetary Economics, 82, 85-106. https://doi.org/10.1016/j. jmoneco.2016.07.006

Maier, P. (2010). How central banks take decisions: An analysis of monetary policy meetings Challenges in central banking (pp. 320-356). Canada: Bank of Canada.

Medhioub, I., \& Jedidia, L. B. (2017). GCC monetary union and the transmission of business cycles: evidence from temporal correlations. International Journal of Monetary Economics and Finance, 10(1), 1-23.

Nawatmi, S., Nusantara, A., Santosa, A. B., Marlien, M., \& Udin, U. (2019). Globalization Impact on ASEAN Countries Inflation. International Journal of Innovation, Creativity and Change, 9(7), 155-162.

Rahman, M., \& Mustafa, M. (2017). Financial deepening and stock market returns: panel data analyses for selected developed and developing economies. International Journal of Monetary Economics and Finance, 10(1), 96-109.

Sethi, M., Baby, S., \& Dar, V. (2019). Monetary Policy Transmission during Multiple Indicator Regime: A Case of India. Journal of Asian Finance, Economics and Business, 6(3), 103-113. https:// doi.org/10.13106/jafeb.2019.vo16.no3.103

Tung, L. T. (2019). Does the Gap between Domestic and International Gold Price Affect Money Demand? Evidence from Vietnam. Journal of Asian Finance, Economics and Business, 6(3), 163-172. https://doi.org/10.13106/jafeb.2019. vol6.no3.163 